\title{
Psalm 97: Almal moet bly wees, want Jahwe is Koning
}

W S Prinsloo

Universiteit van Pretoria

\begin{abstract}
Psalm 97: The Lord is king! Let all the world rejoice

In this article, which was presented as a paper at the congress of South African and Dutch Old Testament Scholars, the author first positions himself methodologically in terms of the South African situation. He then proceeds to use Psalm 97 to illustrate the text-immanent method, the method which he elects to apply. The findings reached are that, although this psalm derives much of its content from the remainder of the Old Testament, it nevertheless forms a coherent whole, and it can be described as an artistic poem in which various techniques of poetry are employed. However, Psalm 97 does not contain a clearly demarcated or even symmetrical strophic division. It is a persuasive text which probably dates from the post-exilic period. Apparently, the main aim of the psalm was to convince the reader/listener that the Lord is in command.
\end{abstract}

\section{INLEIDING}

Die idee dat daar so iets bestaan soos die objektiewe lees van 'n teks en dat daar so iets is soos een ware betekenis van 'n teks wat net ontsluit moet word, is tereg deur reader response benaderings as ' $n$ illusie ontmasker. Tog moet die ander uiterste, naamlik dat 'n teks ' $n$ oneindige aantal betekenisse het en dat die toekenning van betekenis geheel en al by die leser of hoorder berus, ook ernstig bevraagteken word (Berlin 1993:143). Dit kan lei tot 'the feeling that anything goes' (Rogerson 1991:383). 'n Middeweg tussen die twee uiterstes lyk na die mees verantwoordbare benadering (Berlin 1993:143): Aan die een kant moet daar erken word dat die leesproses 'n kreatiewe proses is en dat

* Voordrag gelewer op 12 Julie 1995 in Leiden, Nederland as deel van die kongres tussen Afrikaanssprekende en Nederlandssprekende Ou-Testamentici.

* Hiermee word erkenning gegee aan die Sentrum vir Wetenskapsontwikkeling (SWO) vir 'n ad hoctoekenning. Menings wat hier uitgespreek word, is dié van die skrywer en nie noodwendig dié van die SWO nie. 
die leser iets na die teks toe bring en iets met die teks maak. Aan die ander kant oefen 'n teks ook ' $n$ invloed uit op hoe dit gelees behoort te word'. 'n Teks bestaan tog uit woorde, sinne en grammatikale konstruksies. 'n Teks het tog sekere eienskappe (Berlin 1993:145) en daar is iets soos die interne literêre konteks van 'n teks, en sekere taalkonvensies en relasies tussen sekere dele van die teks. As daar nie so 'n gemeenskaplike grond was nie sou dit beswaarlik moontlik gewees het om gesamentlik oor 'n teks te praat en sou selfs die beoefening van die Ou-Testamentiese wetenskap nie moontlik gewees het nie.

Binne die Suid-Afrikaanse konteks het die Ou-Testamentiese wetenskap hom veral sedert die sewentigerjare lank en intensief besig gehou deur te praat oor die een regte metode ${ }^{2}$. 'n Mens sou kon vra of die strewe na die regte metode dalk toegeskryf kon word aan die apologetiese houding van sommige Suid-Afrikaners, veral gedurende die apartheidsera toe dit nodig was om telkens teenoor hulleself en die buitewêreld te verduidelik dat hulle dinge op die korrekte manier doen. Dié fase van ons wetenskapsbeoefening is egter gelukkig nou verby sodat daar ruimte en begrip is vir 'n verskeidenheid van eksegetiese benaderings ${ }^{3}$.

Le Roux (1993) het in sy boek, A story of two ways: Thirty years of Old Testament scholarship in South Africa, aangetoon dat daar veral twee hoofstrome in die Ou-Testamentiese navorsing in Suid-Afrika aangewys kan word, naamlik 'n historiese[-kritiese] stroom en wat ' $n$ mens ' $n$ teksimmanente benadering sou kon noem. Ek vind my meer by laasgenoemde benadering tuis. Ek onderskryf gevolglik die woorde van 'n bekende Ou-Testamentikus wat so kort gelede as 1993 uitgespreek is: '... taking a synchronic approach to the text in its given shape is a task Old Testament scholarship has neglected too long and too intentionally. Scholars still seem to be proud of knowing things better than the final redactors or compilers' (Rendtorff 1993:52).

Hoewel daar al baie gedoen is op die terrein van detailteksuitleg in Suid-Afrika, was ons in die verlede miskien nog te veel aangewese op byvoorbeeld Europese kommentare en kan daar myns insiens nog veel meer in hierdie verband deur ons gedoen word. My bydrae moet dus gesien word as 'n poging om die detailuitleg van tekste verder te bevorder en as ' $n$ voorbeeld van hoe ten minste sommige Ou-Testamentici in Suid-Afrika probeer werk ${ }^{4}$.

Die teksimmanente benadering wat ek probeer illustreer, sou ek egter graag as 'n kreatiewe handeling wil sien wat poog om reg te laat geskied aan al die verskillende fasette van die teks. Soos wat hopelik uit die res van die artikel sal blyk, sou dit onbillik wees om die benadering, soos geillustreer aan die hand van Psalm 97, as a-histories, strukturalisties of selfs as verbeeldingloos te bestempel. 


\section{2. 'N TEKSIMMMANENTE BENADERING TOT PSALM 97}

Wat die interpretasiegeskiedenis van Psalm 97 betref, tree dieselfde probleme weer en weer na vore: Psalm 97 deel saam met die ander sogenaamde troonsbestygingspsalms die problematiek van hoe die uitdrukking יִּוֹ verstaan moet word ${ }^{5}$. Terwyl sommige navorsers die psalm aan 'n spesifieke kultiese situasie, soos byvoorbeeld die sogenaamde troonsbestygingsfees verbind ${ }^{6}$, of selfs 'n Gattung-bepaling daarvan maak deur van ' $n$ troonsbestygingslied te praat ${ }^{7}$, ontken ander weer dat daar hoegenaamd so 'n Gattung soos 'n troonsbestygingslied is ${ }^{8}$. Dit lei daartoe dat daar ook ander voorstelle tot Gattung-bepaling gemaak word ${ }^{9}$. Terwyl sommige eksegete die psalm eskatologies verstaan ${ }^{10}$, word dit deur ander weer aan 'n spesifieke historiese situasie gekoppel ${ }^{11}$. Pogings om die psalm te dateer wissel van die voor-eksiliese ${ }^{12}$ tot die naeksiliese tyd ${ }^{13}$. Sommige verklaarders dateer een deel van die psalm voor-eksilies en 'n ander deel van die psalm weer na-eksilies ${ }^{14}$.

Daar is ook twee uiteenlopende standpunte wat die eenheid en opbou van die psalm betref. Enersyds is daar diegene wat dit as 'n planvolle eenheid sien ${ }^{15}$ en andersyds diegene wat dit nóg as 'n planvolle teks van een outeur nóg as 'n planvolle antologiese komposisie beskou ${ }^{16}$. Sommige navorsers gebruik juis die antologiese karakter van die psalm of selfs vormkritiese argumente om glosses of latere redaksionele byvoegings aan te duil ${ }^{17}$. Ook wat die strofale indeling van die psalm betref is daar wyduiteenlopende menings ${ }^{18}$ aan die orde.

'n Aspek wat sterk in die resente psalmnavorsing na vore tree - en wat ook veral by Psalm 97 relevant is - is om die psalms as koherente boek te lees en om die verbande tussen verskillende psalms te probeer nagaan ${ }^{19}$. Dit spreek vanself dat dit belangrik is - ook vir die verstaan van Psalm 97 - om die samehang tussen byvoorbeeld Psalm 93 tot 97 na te gaan 20 .

Wanneer ek vervolgens Psalm 97 probeer lees, moet u egter nie van my verwag om 'n presiese rekonstruksie van die sogenaamde kultiese situasie of die historiese Sitz daarvan te probeer maak nie. Net so min moet $u$ van my verwag om op grond van 'n teoreties gerekonstrueerde Gattung - ala Gunkel - 'n Gattung op Psalm 97 af te dwing nie. ' $n$ Kenmerk van Psalm 97 is die saamgestelde of antologiese aard daarvan. Daar is feitlik geen deel van die psalm wat nie aan 'n ander deel van die Ou Testament ontleen is nie 21 . Hier word daar egter nie gepoog om Psalm 97 in terme van dié tekse te verklaar of om die groeiproses te rekonstrueer waarlangs Psalm 97 sou ontstaan het nie. Hier word dus op die teks gekonsentreer soos wat dit tans voor ons $1 \mathbf{e}^{22}$. Aandag word veral aan morfologiese, sintaktiese, stilistiese en semantiese sake gegee. 
Die eerste wat opgemerk word by 'n noukeurige deurlees van die psalm, is die woordgebruik en woordherhalings. Dié stylfiguur wek die indruk van kohesie en deur daarop te let, kan daar reeds voorlopige afleidings oor die vernaamste temas in die psalm gemaak word. Die opvallendste woordherhaling is die stam שמש wat nie minder nie as vier keer, naamlik in 1b, 8a, 11 b en 12 voorkom. Watson (1986:284) wys met reg op die 'envelope figure' wat bewerk word deur dié stam aan die begin en einde van die psalm. Net so opmerklik is die stam צדק wat verspreid deur die psalm voorkom,

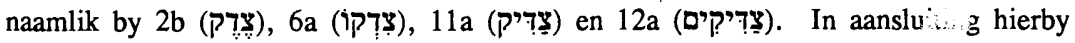

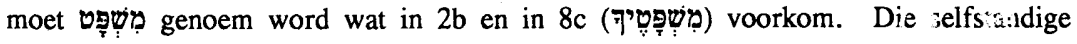

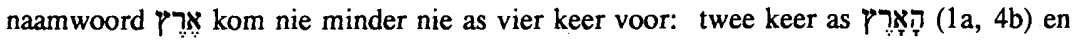

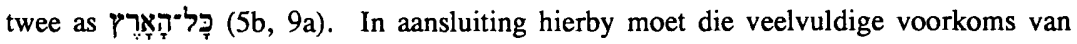

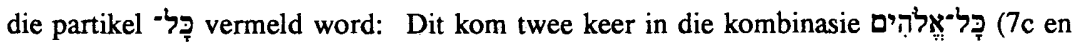

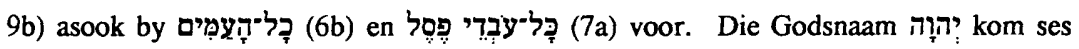
keer (1a, 5a, 8c, 9a, 10a, en 12) voor. Die groot klem op יהוֶ? hoog deurdat Hy ook as fikse wat na Hom verwys. Die werkwoordstam גיל ('juig') kom op twee plekke voor. In 1a met die 'aarde' as subjek en in $8 \mathrm{~b}$ met die 'dogters van Juda' as subjek. In beide gevalle kom dit in die onmiddellike konteks van die werkwoordstam שמח voor. Die

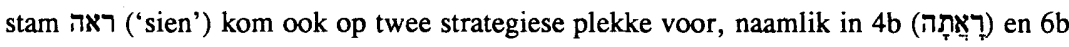

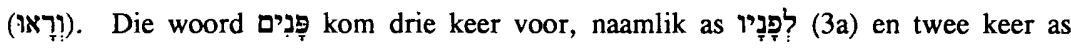

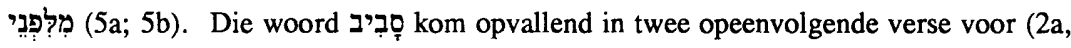

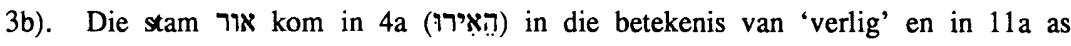
selfstandige naamwoord 'lig' (אוֹ) voor. Al hierdie woordherhalings bewerk, soos wat reeds opgemerk is, samehang in die psalm. Die spesifieke doel van elkeen van die woordherhalings kan egter eers bepaal word nadat daar in die geheel na die psalm gekyk is.

Na hierdie oor $y$ kan daar nou meer gedetailleerd na die psalm gekyk word: Die psalm word in 1a ingelei met die emfatiese konstatering in die perfektum dat Jahwe as koning regeer ${ }^{23}$. Dit word opgevolg deur twee jussiewe (תָ, 1a; 'n oproep tot vreugdevolle reaksie op die koningskap van Jahwe gemaak word. Die laaste gedeelte van $1 \mathrm{a}$ en $1 \mathrm{~b}$ is parallel opgebou:

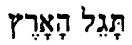

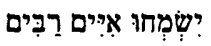


$1 \mathrm{~b}$ vertoon egter progressie op die voorafgaande in die sin dat die meervoudsvorm van die werkwoord en die uitdrukking רִיים ('baie eilande') die gedagte van die universalistiese reikwydte van Jahwe se koningskap nog meer versterk.

Vers 2-6 sou beskryf kon word as die effek van Jahwe se koningskap op die totale skepping. Veral 2-5 sou aangedui kon word as 'n teofanieskildering met talle geykte uitdrukkings met veral terminologie uit die Sinaitradisie (vgl veral Eks 19:16; Eks 20:21; Deut 5:22) ${ }^{24}$. Dit is egter belangrik om daarop te wys dat die geykte terminologie 'n nuwe en unieke funksie binne hierdie psalm verkry ${ }^{25}$. Hier sou gepraat kon word van die heerlike en verskriklike verskyning van God om sy ryk in besit te kom neem (Gunkel 1986:424). Opvallend genoeg word die koms van Jahwe self nie beskryf nie, maar slegs 'die Begleitmomente' (Jeremias 1987:138) van sy koms en die reaksie op sy koms.

Binne die gedeelte 2-6 sou daar egter ook nog nadere verbindinge aangewys kon word: 2a-4a lê veral naby aanmekaar vanweë die derdepersoon suffikse wat na Jahwe

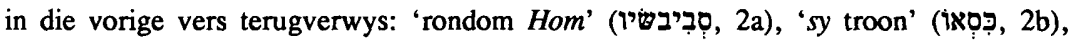

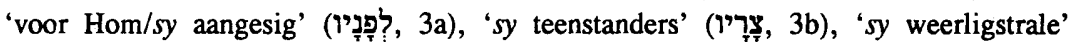

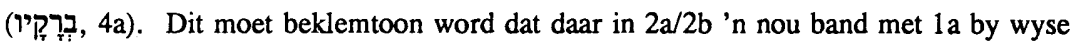
van die derdepersoon suffikse asook deur die heropname van die koningskap van Jahwe by wyse van die woord 'sy troon' bewerkstellig word.

$2 a$ en $2 b$ is parallel opgebou:

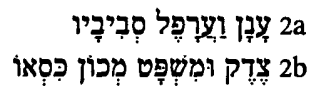

Beide versdele bestaan uit twee woordpare en beide is nominale sinne. Albei eindig op die derdepersoonenkelvoud suffiks wat na Jahwe verwys. Die metafoor by $2 \mathrm{a}$ laat die klem op die onsigbaarheid, verborgenheid en ondeurgrondlikheid van Jahwe val ${ }^{26}$. Hoewel die twee versbene oënskynlik 'n teenstelling vorm, wil dit tog gesamentlik sê dat hoe ondeurgrondelik Jahwe ook al is, geregtigheid en reg ${ }^{27}$ die grondslag van sy koningskap is (Valeton 1913:143).

Die twee versbene van 3 is ook parallel opgebou en word by wyse van 'n wawtram..intief verbind:

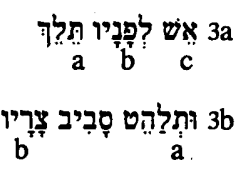


Die 'ballast variant' 28 stylfiguur word hier gebruik deurdat element $\mathrm{c}$ (die subjek) nie eksplisiet by $3 b$ voorkom nie. Om die balans te behou en om te vergoed vir die afwesigheid van element $c$ word element $b$ by $3 b$ dus uitgebou. Daar is ook 'n chiastiese relasie tussen die twee versbene wat betref die plasing van die werkwoord (element a). $3 b$ is ' $n$ nadere presisering van $3 a$ in die sin dat die geweldige uitwerking van die vuur in $3 \mathrm{~b}$ geteken word. Vuur is ' $\mathrm{n}$ belangrike element by die beskrywing van teofanieë (vgl bv Eks 19:18; 24:17; Deut 5:4; 9:10, 15; 18:16). Hier word die vuurmotief metafories aangewend om die skrikwekkende koms van Jahwe aan te dui. Die hele beskrywing hier wek die indruk dat Jahwe sy vyande oorwin het sonder om self 'n vinger te verroer.

'n Noue relasie word tussen $2 \mathrm{a} / 2 \mathrm{~b}$ en $3 \mathrm{a} / 3 \mathrm{~b}$ bewerk deur die heropname van die woord סָרב in 3b. Bowendien is daar ook 'n chiastiese relasie te bespeur wat die plasing van die woord betref (Van der Lugt 1980:363). Hierdie stylfiguur en die woordopname het ' $n$ kontrasterende effek, want in $2 a$ word die woord in terme van die 'heerlikheid' van Jahwe gebruik, maar in $3 a$ in terme van die vernietiging van die vyande.

By 4 word die teofaniese beskrywing van die voorafgaande deel voortgesit. Die heropname van die derdepersoon suffiks ('sy weerligstrale') bevestig ook die verband met die voorafgaande. By $4 \mathrm{a} / 4 \mathrm{~b}$ is daar egter ' $\mathrm{n}$ verskil te bemerk in die sin dat die

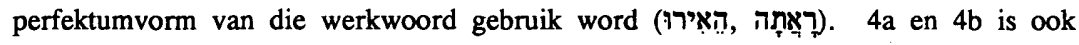

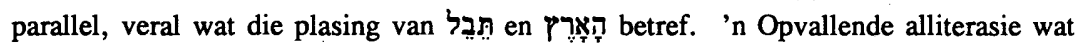

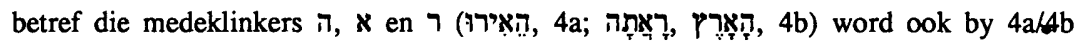
aangetref. Daar bestaan egter 'n asindetiese verhouding tussen die twee versbene (Beuken 1974:103): 4a sê dat 'sy weerligstrale' die לבֶ verlig en in 4b word die reaksie van die aarde geteken. Personifikasie van die aarde vind plaas om die reaksie nog meer te beklemtoon.

In 4b word ook 'n opvallende band, 'n mens sou dit ook 'n inclusio kon noem, met

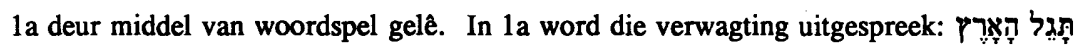

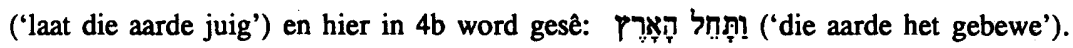
Die verwagting van $1 \mathrm{a}$ het dus oënskynlik nie gerealiseer nie. Dit moet egter vermeld word dat הָאר van 1a en dié van $4 \mathrm{~b}$ nie noodwendig dieselfde betekenis het nie. Dit lyk of van 1a die betekenis van die 'wêreld' of 'al die mense' het terwyl die van $4 \mathrm{~b}$ 'n meer kosmiese betekenis het. Die kosmos reageer dus anders op die koms van Jahwe as wat daar van die mense verwag word.

Die kosmiese reaksie op die koningskap van Jahwe word in $5 \mathrm{a} / 5 \mathrm{~b}$ voortgesit. Deur gebruik te maak van 'n epifoor - deurdat sowel $4 \mathrm{~b}$ as $5 \mathrm{~b}$ op הָארֶ eindig - word die band tussen $5 \mathrm{a} / 5 \mathrm{~b}$ en die vorige vers nog meer verstewig. Die funksie van die epifoor 
is waarskynlik om aan te toon dat die 'aarde' wat bewe (4b) aan Jahwe onderdanig is (5b). Die meervoudsperfektum werkwoordvorm wat by $4 \mathrm{a}$ aangetref is, word by $5 \mathrm{a}$ voorgesit (נִֶָ, 'hulle het gesmelt') ${ }^{29}$. In dié $\sin$ is $6 \mathrm{a} / 6 \mathrm{~b}$ ook nou aan $5 \mathrm{a} / 5 \mathrm{~b}$ gekop-

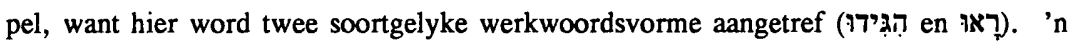

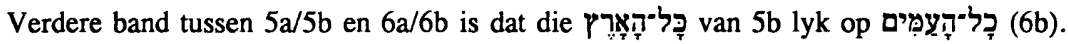
Daar is ook alliterasie (cf van der Lugt 1980:363) ten op sigte van die eerste twee woorde van 4a (הָאִירו) en 5a (הָרים). Hierdie sake bevestig dat 4a/4b sterk na onder koppel. Daar is reeds gewys op die feit dat 2-4 nou aanmekaar gekoppel is. Om die rede moet $4 \mathrm{a} / 4 \mathrm{~b}$ as 'n skarnier of nexus beskou word.

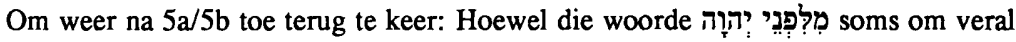
metriese gronde as 'n glosse beskou en gevolglik uitgelaat word ${ }^{30}$, word die MT egter aanvaar aangesien die uitdrukking hier waarskynlik doelbewus gebruik word om die gedagte van Jahwe se teenwoordigheid nog meer te beklemtoon ${ }^{31}$. Die twee versbene kan soos volg voorgestel word:

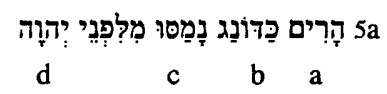

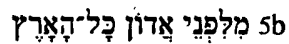

d

Hieruit kan gesien word dat slegs een element van 5a, naamlik element d, uitgebou word om 'n hele versbeen te vorm. Deur die herhaling van ('voor die aangesig

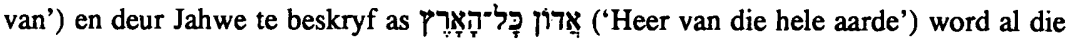
klem op die teenwoordigheid en koms van Jahwe as die universele koning gelê. Deur gebruik te maak van die ellips - die feit dat elemente a, b en c wat in 5a voorkom, maar slegs by $5 \mathrm{~b}$ veronderstel word - word dié gedagte nog meer onderstreep. Deur

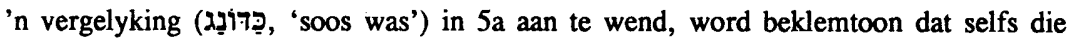
berge, die simbool van permanensie, soos niks verdwyn wanneer Jahwe as koning verskyn.

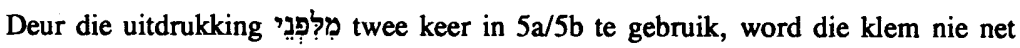
op die ontsagwekkende teenwoordigheid van Jahwe gelê nie, maar word daar ook 'n

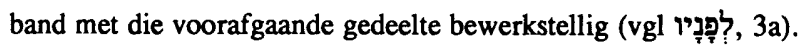

$6 \mathrm{a} / 6 \mathrm{~b}$ is ook parallel opgebou: 


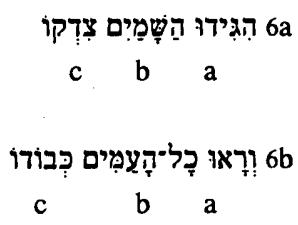

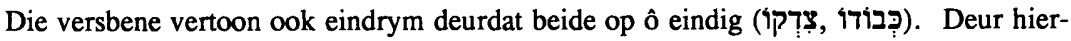
die eindrym word Jahwe se geregtigheid en heerlikheid met mekaar in verband gebring. Eintlik is daar ' $n$ dubbele eindrym aangesien beide voorafgaande woorde op י': eindig

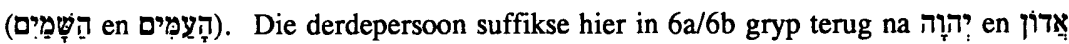
in $5 \mathrm{a} / 5 \mathrm{~b}$ en plaas die klem weer eens op Jahwe - in hierdie geval op, wat in terme van die hele psalm gesien, sy koningsattribute genoem sou kon word. Daar kan met reg

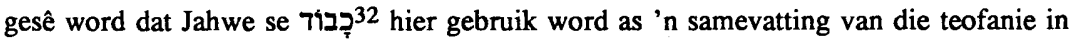
die voorafgaande verse en as 'n oorkoepelende term 'for the royal apparel of God, which is composed of cloud, fire and lightning' (Mettinger 1982:119). Die parallelle wyse waarop $6 \mathrm{a} / 6 \mathrm{~b}$ opgebou, is voer die voorafgaande teofanie ook na 'n klimaks toe 33 .

Daar is reeds gewys op die feit dat $6 \mathrm{a} / 6 \mathrm{~b}$ teruggryp na die voorafgaande verse. Die derdepersoon suffikse hier in $6 a / 6 b$ lê 'n verdere band met die voorafgaande $2 a-4 b$ waar, soos reeds aangetoon, dieselfde verskynsel ook voorkom. Deur die heropname van die woord צֶ vanuit $2 \mathrm{~b}$ word die band met die voorafgaande nog meer versterk.

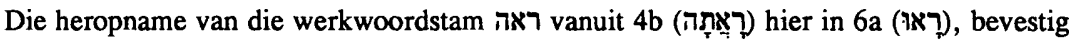
die band nog meer en beklemtoon die reaksie van die skepping op die koningskap van Jahwe. Beuken (1974:104) wys tereg daarop dat die gebruik van woorde soos 'die hele aarde', 'al die volke', 'berge' en 'hemele' in 5a-6b daarop dui dat die hele skepping op die koms van Jahwe as koning reageer. 'n Hiperboliese uitdrukking soos die volke') in $6 b$ versterk ook die band met $1 b$ (אִיים רְבִִּים, 'baie eilande') en bring die universaliteit van Jahwe se koningskap nog meer na vore. Die ineengeweefdheid van die teks word nog verder geïlustreer wanneer gelet word op die simmetriese wyse

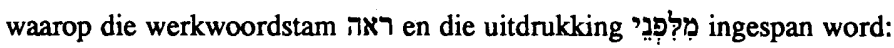

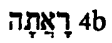

5a

5b

רָ $6 \mathrm{~b}$ 
Wanneer daar weer na die hele gedeelte 1a-6b teruggekyk word, word dit duidelik dat daar nie sulke duidelike afgebakende strofes is soos wat soms beweer word nie ${ }^{34}$. Die feit dat daar so 'n groot verskeidenheid van moontlike strofale iridelings (vgl nota 20) voorkom, bevestig hierdie waarneming. Daar moet dus eerder van 'n ingewikkelde netwerk van verbindinge as van waterdigte strofes gepraat word. Dit impliseer egter nie dat Psalm 97 ' $\mathrm{n}$ onsamehangende gedig is nie.

By vers 7 is daar egter ' $n$ verandering op te merk. Terwyl die vorige verse van beeldryke, geykte teofaniese terminologie gebruik maak, gaan dit hier om 'n 'down to earth' beskrywing. Gunkel (1986:425; vgl ook Gunkel 1917:137) sê dat terwyl vers 26 in 'phantastich-mythologischen' kleure geteken word, gaan dit in 7 en volgende verse meer om 'die Dingen dieser Welt'. 7a word ook van die direk voorafgaande onderskei, aangesien dit 'n werkwoord in die imperfektumvorm het in onderskeid van die voorafgaande perfekta. In onderskeid van die voorafgaande tweeledige vers, bestaan 7 uit drie versbene.

Die verhouding tussen die drie dele van 7 sou soos volg omskryf kon word: $7 \mathrm{~b}$ gee 'n nadere omskrywing van die ('dienaars van afgodsbeelde') van 7a. Die

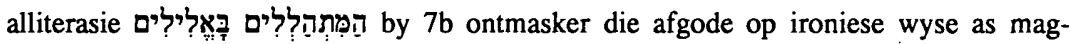
telose skynwesens. Dié beskrywing staan in kontras met die deel van die psalm waar Jahwe as magtige koning beskryf word. Die noue relasie tussen $7 \mathrm{a}$ en $7 \mathrm{~b}$ sou as 'n ellips beskryf kon word, aangesien die werkwoord van 7a ('tot skande kom') slegs by $7 \mathrm{~b}$ veronderstel word. Hoewel 7c op soortgelyke wyse as 7a opgebou is ( $\mathrm{vgl} \mathrm{Mowinc-}$ kel 1957:19), staan dit tog in kontras daarmee: Terwyl die aanbidders van afgodsbeelde tot skande sal kom (7a), sê $7 \mathrm{c}$ dat die gode self in aanbidding voor Jahwe neer$\mathrm{val}^{35}$. Die kontras word nog verder versterk deurdat $7 \mathrm{a}$ van 'al die afgodedienaars' en $7 \mathrm{c}$ van 'al die gode' praat. Hierin gryp sowel $7 \mathrm{a}$ as $7 \mathrm{~b}$ terug na $5 \mathrm{~b}$ (קָ)

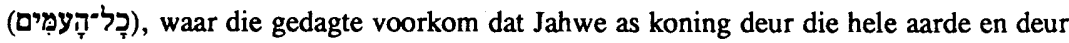
alle volke erken word.

Vers 8-9 is die enigste gedeelte van die psalm waar Jahwe direk aangespreek word. Dit blyk uit die tweedepersoon suffiks by $8 \mathrm{c}$ (苞) en uit die persoonlike voor-

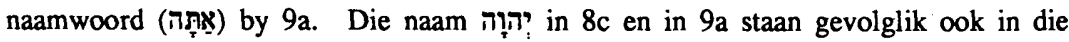
vokatief. Die verwisseling vanaf die derdepersoon na die tweedepersoon, dui aan dat die verkondiging hier in ' $n$ belydenis verander (cf Beuken 1974:107). Die uitdrukking

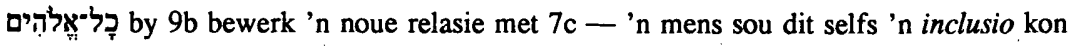
noem (vgl Van der Lugt 1980:363) — waar dieselfde uitdrukking voorkom. Hierdeur word Jahwe se mag oor die afgode weer eens beklemtoon. 
Vers 8 , is soos vers 7 , 'n driebenige vers. $8 \mathrm{a}$ en $8 \mathrm{~b}$ is parallel opgebou:

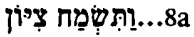 \\ b $\quad$ a

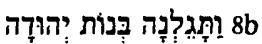

b a

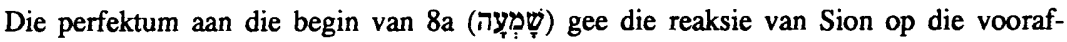
gaande gebeurtenisse weer (die koningskap van Jahwe en alles wat daarmee saamhang)

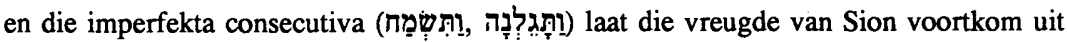
die feit dat hulle die nuus gehoor het (Michel 1960:25; Beuken 1974:105). 8a en 8b mond in $8 \mathrm{c}$ uit waar die rede vir die blydskap van Sion, naamlik die regspraak van Jahwe, aangegee word. Die opvallende ooreenkoms tussen vers 8 en 1 moet ook onderstreep word. Beide woorde waarmee blydskap uitgedruk word (שמח, (שיל) kom ook - weliswaar in chiastiese orde - by $1 \mathrm{a} / 1 \mathrm{~b}$ voor. Die verskil is dat die jussief ten opsigte van die wêreld en die eilande by $1 \mathrm{a} / 1 \mathrm{~b}$ as gerealiseerd ten opsigte van die Godsvolk in $8 \mathrm{a} / 8 \mathrm{~b}$ geteken word. Die wens van $1 \mathrm{a} / 1 \mathrm{~b}$ is universeel geformuleer, terwyl die realisering daarvan op Juda toegespits word. Die reaksie van die 'dogters van

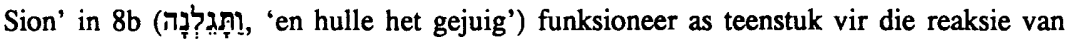

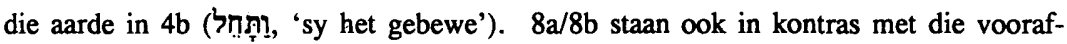
gaande $7 \mathrm{a} / \mathrm{b} / \mathrm{c}$ : Terwyl 'Sion' en die 'dogters van Juda' bly is en juig ( $8 \mathrm{a} / 8 \mathrm{~b})$, sal die 'dienaars van afgodsbeelde' tot skande kom. 'n Verdere verbinding van vers 8 met die begin van die psalm is dat in $2 b$ Jahwe se koningskap geteken word en dat hier in $8 \mathrm{c}$ sy

Daar is reeds gewys op die feit dat daar 'n noue verbinding tussen $8 a / 8 b$ en $9 a / 9 b$ is. Dié verbinding word nog meer versterk deur die partikel Of die partikel redegewend ('want') funksioneer as verdere motivering vir die blydskap (vgl bv Van der Ploeg 1974:156), en of dit 'n emfatiese funksie het (vgl bv Beuken 1974:106) en as 'waarlik' of 'voorwaar' vertaal moet word, is nie so duidelik nie. Die twee versbene van 9 vertoon talle parallelle trekke:

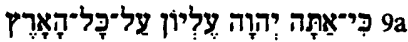

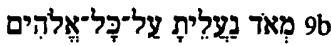

Sowel $9 \mathrm{a}$ as $9 \mathrm{~b}$ beskryf die verhewenheid van Jahwe. Opvallend by beide bene is die alliterasie en woordspel wat betref die medeklinkers $y$ en ל. Dit hang natuurlik direk saam met die werkwoordstam (עלה) en die voorsetsel (על) waarmee die verhewenheid 
beskryf word. Die twee versbene eindig ook op analoë wyse. Hierdeur word beklemtoon dat die verhewenheid/koningskap van Jahwe oor die hele aarde en oor alle gode geld. Hiermee sluit $9 \mathrm{a} / 9 \mathrm{~b}$ aan by die res van die psalm (vgl onderskeidelik $5 \mathrm{c}$ en $7 \mathrm{c}$ ) waar die gedagte ook aangetref word.

10a word van die voorafgaande deel onderskei deurdat die direkte aanspreekvorm van Jahwe onderbreek word en daar weer oor Hom in die derdepersoon gepraat word. Nog 'n verskil met die voorafgaande is dat $10 \mathrm{a}$ 'n vermaning is - in die vorm van 'n

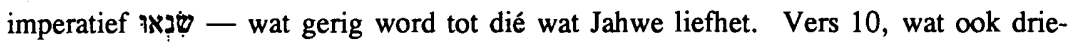
ledig ingedeel kan word, se interpretasiegeskiedenis word hoofsaaklik deur 'n tekskritiese voorstel gekenmerk ${ }^{36}$. Hoewel dié voorstel 'n makliker tekslesing teweeg sou bring, ontbreek die nodige teksgetuies egter daarvoor en word die MT hier aanvaar omdat die interpretasie daarvan ook nie onoorkomelike probleme skep nie ${ }^{37}$.

Daar is sterk gronde wat aangevoer kan word waarom die gedeelte 10-12 ' $n$ eenheid vorm ${ }^{38}$. Eerstens moet opgemerk word dat dit die enigste gedeelte van die psalm

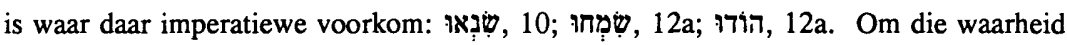
te sê, die imperatiewe vorm ' $n$ inclusio sodat 10-12 'n afgeronde eenheid uitmaak. Die imperatiewe word ook almal tot dieselfde mense gerig, naamlik die Jahwe-gelowiges.

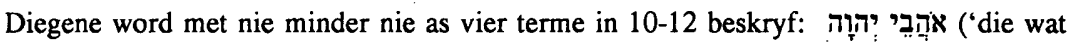

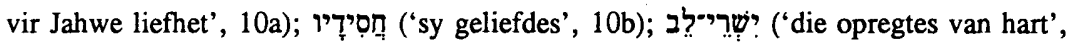
11b); צִִּּיקים ('regverdiges', 12a). Nog 'n opvallende kenmerk van die gedeelte is dat dit terminologie gebruik wat kenmerkend van die wysheidsliteratuur is. Hier kan onder

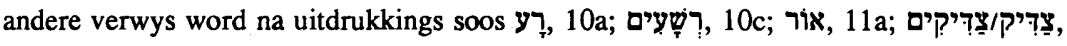

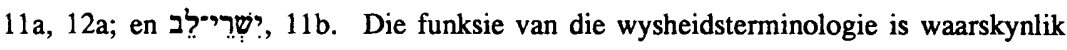
om die kontras tussen die regverdiges en die goddeloses - en eintlik ook tussen Jahwe en die afgode - nog meer te beklemtoon.

Oor 10, wat ook 'n drieledige vers is, kan die volgende opmerkinge gemaak word: Oor die algemeen val die polariteite hier op. Dit sou dalk ook verband kan hê met die wysheidsterminologie waarop die aandag hierbo reeds gevestig is: In 10a staan

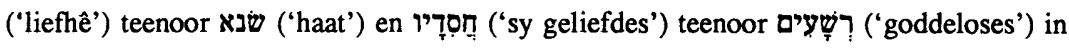
onderskeidelik $10 \mathrm{~b}$ en 10c. Die verhouding tussen die drie versbene sou verder soos volg uitgedruk kon word: Terwyl $10 \mathrm{a}$ 'n vermaning is wat tot die 'liefhebbers' van Jahwe gerig word, beskryf $10 \mathrm{~b}$ wat Jahwe vir diesulkes doen. 10b gryp terug na 10a

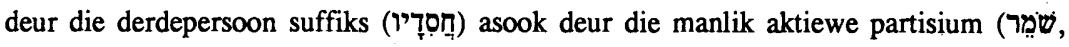

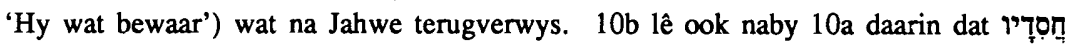

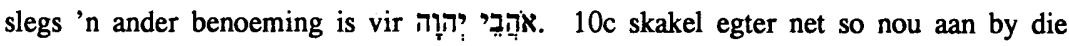
voorafgaande $10 \mathrm{~b}$. $10 \mathrm{c}$ sou beskou kon word as 'n nadere presisering van $10 \mathrm{~b}$ - in die sin dat daar nou uitgespel word wat שִ inhou, naamlik dat Jahwe sy geliefdes red 
uit die hand van die die 'goddeloses'. Die derdepersoonmeervoud suffiks van 10c ('Hy red hulle') gryp terug na en lê 'n verdere band met $10 \mathrm{~b}$. Wat die plasing van die werkwoorde betref, is daar ' $\mathrm{n}$ oorkruisrelasie tussen $10 \mathrm{~b}$ en $10 \mathrm{c}$ te bespeur.

$11 \mathrm{a}$ en $11 \mathrm{~b}$ is ook chiasties opgebou:

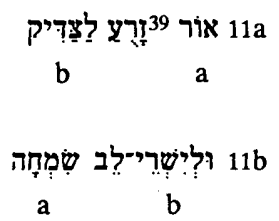

Die verbinding word nog verder versterk deur ' $n$ ellips deurdat die werkwoord wat by 11 a voorkom, slegs by $11 \mathrm{~b}$ veronderstel word. Die passiewe vorm van die werkwoord moet in die lig van 10c as ' $n$ indirekte verwysing na Jahwe gesien word. 11a vertoon dus ook in een opsig ' $n$ kontras met die begin van die psalm: terwyl donkerte Jahwe omring (vgl 2a), is Hy ook die een wat lig (11a) uitdeel.

$12 \mathrm{a}$ en $12 \mathrm{~b}$ is uiteraard baie nou aan mekaar verbonde. Die twee versbene is parallel opgebou:

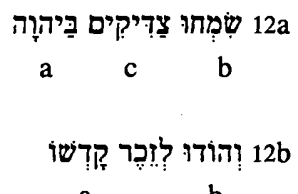

Hier word weer eens 'n ellips gebruik deurdat element $\mathrm{c}$ by $12 \mathrm{a}$ (diegene tot wie die imperatief gerig word) slegs by $12 \mathrm{~b}$ veronderstel word. Die derdepersoon suffiks -

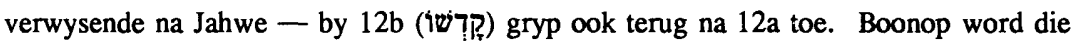
twee versbene aan mekaar verbind by wyse van ' $n$ waw-kopulatief (itiin).

Dit is ook belangrik om daarop te wys dat $12 \mathrm{a} / 12 \mathrm{~b}$ en die voorafgaande $11 \mathrm{a} / 11 \mathrm{~b}$ baie nou verbind is. Eerstens by wyse van die stylfiguur van anadiplose ${ }^{40}$ deurdat $11 \mathrm{~b}$ op die stam שמת eindig en 12a weer daarmee begin. Nog 'n opvallende woordopname

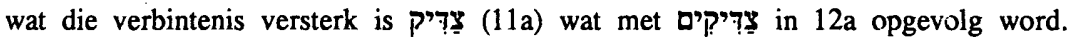
$11 \mathrm{a} / 11 \mathrm{~b}$ handel oor 'lig' en 'blydskap' wat aan die (let op die voorsetsel ?̧) regverdiges gegee word. $12 \mathrm{a} / 12 \mathrm{~b}$ handel oor die regverdiges wat opgeroep word om blydskap en dank - aan Jahwe (weer eens die voorsetsel ??, 12b) terug te gee. 12a/12b staan ook in 'n antitetiese relasie tot 7a/7b: terwyl die 'dienaars van afgodsbeelde' (7a) tot skande sal kom, kan die 'regverdiges' met blydskap reageer (12a/12b). 
Hierdie laaste gedeelte vervul ook 'n belangrike oorkoepelende funksie ten opsigte van die psalm as geheel. Daar is reeds gewys op die feit dat daar ' $n$ afgerondheid bewerk word deur die stam שמח wat in die eerste en in laaste vers van die psalm voorkom. Dit word nog meer versterk deurdat die naam Jahwe ook in die eerste en die laaste vers voorkom. Eintlik moet daar van 'n dubbele inclusio gepraat word, want die stam צom in sowel die tweede (2b) as die tweede laaste vers (11a, cf ook 12a) voor. Hoewel die dubbele inclusio 'n afgerondheid bewerkstellig, verteenwoordig dit tog ook 'n progressie op die begin van die psalm. In $1 \mathrm{~b}$ word die wêreld by wyse van

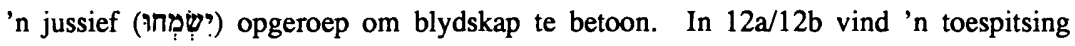

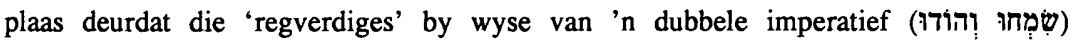
opgeroep word om blydskap te betoon. Aan die begin van die psalm vorm die stam צ צeel van die beskrywing van die koningsattribute van Jahwe (cf cok ịŢ, 6a). Aan die einde van die psalm word dit gebruik om diegene wat vir Jahwe liefhet te beskryf.

\section{SAMEVATTEND}

Hoewel Psalm 97 ' $n$ groot deel van sy inhoud aan die res van die Ou Testament ontleen, vertoon dit tog 'n samehangende geheel en sou daar van 'n kunstige gedig gepraat kon word. Ou, geykte stof is op ' $n$ kreatiewe manier geherinterpreteer en in u nuwe, unieke vorm gegiet. Die gedig vertoon deurgaans allerlei literêre tegnieke en poëtiese konvensies soos: woordherhaling en -spel; inclusio; parallelisme en chiasme; ballast variant; ellips; epifoor; anadiplose; personifikasie; hiperbool; alliterasie, assonasie en rym; ironie en kontras. Hierdie stylfigure kom konstant deur die psalm voor, dra gesamentlik tot die samehang by en is nie net ornamenteel van aard nie, maar word ook funksioneel aangewend.

Hoewel daar, soos wat dit in die bespreking na vore getree het, sekere dele van die psalm is wat nader aan mekaar as ander lê, kan daar nie van 'n duidelik afgebakende of selfs simmetriese strofale indeling gepraat word nie. Daarvoor is daar te veel kruis en dwars verbindinge en tekste wat sowel na bo as na onder verwys. Ons het dus by Psalm 97 te doen met 'n geïntegreerde geheel en 'n ingewikkelde netwerk van verhoudinge waarin alles meewerk tot een oorkoepelende doel, naamlik om die leser/hoorder te oortuig dat Jahwe koning is.

Dit is onmoontlik om op grond van die psalm self te bepaal wat die spesifieke oorspronklike historiese en/of kultiese Sitz im Leben van die psalm was. Indien daar egter gelet word op die verskynsel dat Psalm 97 baie van sy stof aan die res van die Ou Testament ontleen, is dit logies dat Psalm 97 jonger as dié dele is - en nie andersom soos 
wat soms beweer word nie. Op grond hiervan sou 'n mens kon sê dat Psalm 97 waarskynlik in die ná-eksiliese tyd gedateer kan word. Op grond van die inligting in die teks self is dit egter nie moontlik om tot 'n nader datering te kom nie en moet daar ongelukkig met hierdie vae aanduiding volstaan word.

Op grond van bostaande opmerkings, op grond van die klem op die koningskap van Jahwe en in die lig van die hele psalm kan gesê word dat Psalm 97 'n oorredende teks is. Die saak waartoe die psalm wil oorreed is dat Jahwe koning is. In die moeilike ná-eksiliese tyd toe die monargie nie meer bestaan het nie - en in alle tye daarna wanneer die godsvolk in krisis sou verkeer - sou die idee dat Jahwe koning is, 'n vertroostende effek gehad het en kon die godsvolk te midde van 'n troostelose situasie, nogtans bly wees. Om weer saam te vat: Alles in die psalm konsentreer daarop om die leser/hoorder te oortuig dat Jahwe koning is.

'n Paar belangrike fasette, wat reeds na vore getree het, kan nou by wyse van samevatting weergegee word: Dwarsdeur die psalm word die klem op verskeie maniere op Jahwe en op sy koningskap gelê. Die gedagte dat die koningskap van Jahwe vreugde inhou vir die 'regverdiges', kom na vore deur die inclusio en deur die herhaling van die stam שמח. Die psalm word deurentyd gekenmerk deur kontraste. Die kontraste versterk ook die gedagte van die koningskap van Jahwe: die vyande van Jahwe word sonder moeite verslaan, terwyl die regverdiges opgeroep word tot blydskap. Die regverdiges word opgeroep tot blydskap, maar die dienaars van afgode sal tot skande kom. Aan die een kant word Jahwe beskryf as ondeurgrondelik, maar aan die ander kant gee Hy tog lig en redding. Jahwe is die swaarwigtige en heerlike, terwyl die gode as liggewigte en skynwesens afgemaak word. Jahwe is verhewe, terwyl die gode laag voor Hom neerbuig. Jahwe se koms en sy teenwoordigheid as koning is ontsagwekkend en dit het 'n uitwerking op die ganse kosmos. Sy koningskap is egter ook gebou op reg en regverdigheid. Die regverdigheid word ook deel van en word gegee aan diegene wat Hom liefhet. Sy koningskap is universeel, maar kom veral tot uiting by diegene wat in Hom glo. In die psalm word daar gepolemiseer teen die afgodsdienaars en afgode. Die moontlikheid moet ook nie uitgesluit word dat die koningskap van Jahwe in Psalm $97 \mathrm{cp}$ indirekte wyse gekontrasteer word met die mislukte voor-eksiliese monargie nie.

Om weer eens saam te vat: Psalm 97 het een hoofdoel voor oë en dit is om die leser/hoorder te oortuig dat Jahwe regeer. Dié wete moes 'n vertroostende effek gehad het op die Jahwe-gelowiges in krisissituasies. 


\section{INDELING VAN PSALM 97 IN VERSBENE}

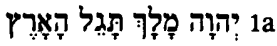

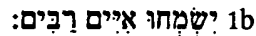

2a 2b

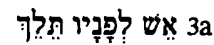

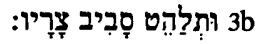

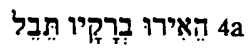

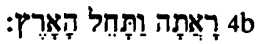

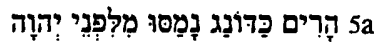

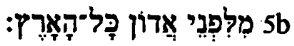

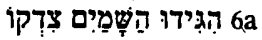

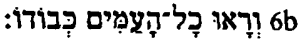

7a

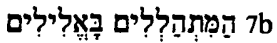

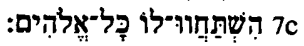

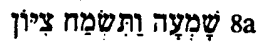
8b $8 c$

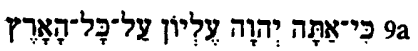

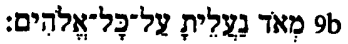

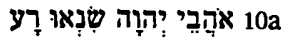

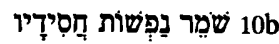
10c

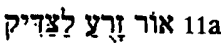

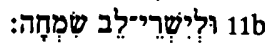

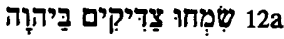

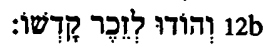


Hierdie is ' $n$ selfstandige indeling van die psalm in versbene. Die indeling word ook deur die meeste ander eksegete onderskryf (vgl bv Kittel 1922:317; Van der Ploeg 1974:154; Gunkel 1986:423-424; Howard 1986:95). Hoewel daar diegene is wat vers 9 as 'n drie-benige vers beskou (vgl bv Mowinckel 1957:17) word dié vers hier egter ook as tweebenig gesien (vgl bv Schmidt 1934:179 wat ook die verdeling ondersteun), omdat ' $n$ drieledige verdeling die parallelisme sou verbreek wat daarin bestaan dat $9 \mathrm{a}$

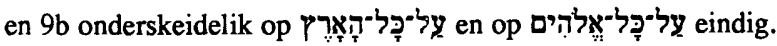

\section{Endnotas:}

1 Vergelyk ook Botha (1989:113-127) wat pleit vir 'n gesonde balans tussen die resepsieteorie en teksimmanente benadering.

2 Vergelyk byvoorbeeld Deist (1973:75-81); Deist (1983:26-48); Deist (1988:39-54); Loader (1978:1-40); Prinsloo (1979:201-210); Prinsloo (1988:196-209); Prinsloo (1990: 144-152); Prinsloo (1992:182-188); Van Zyl (1981:43-50).

3 Kyk Old Testament Essays 7/4 (1994), waarin 'n hele aantal Suid-Afrikaanse OuTestamentici bydraes oor eksegetiese metodes gelewer het, reflekteer juis die uiteenlopendheid van eksegetiese benaderings wat tans in Suid-Afrika aan die orde is. Old Testament Essays is die tydskrif van die Ou-Testamentiese Werkgemeenskap van Suid-Afrika.

4 Oor die afgelope dekade is daar 'n aantal doktorale dissertasies by die departement Ou Testament, Universiteit van Pretoria ingedien waarin dié metode basies gevolg is. Vergelyk byvoorbeeld: Snyman (1985); Coetzee (1986); Botha (1986); Swanepoel (1987); Prinsloo (1989); Viviers (1990); Carelsen (1991); Human (1993); Kirkpatrick (1993); Kriek (1993).

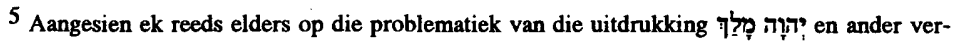
wante probleme ingegaan het, doen ek dit nie weer hier nie (vgl Prinsloo 1993a:248-250; Prinsloo 1993b:622- 630; Prinsloo 1994:156-157). Vergelyk ook Bernhardt (1961) vir 'n oorsig van die navorsingsgeskiedenis in dié verband.

6 Mowinckel is die belangrikste voorstander van die troonsbestygingshipotese. Vergelyk Mowinckel (1961:3-209) en Mowinckel (1962:106-192) vir 'n volledige uiteensetting van sy standpunt. Kyk byvoorbeeld ook Gray (1979:7ev); Lipinski (1963:405-460). Behalwe die troonsbestygingsfees word daar ook ander kultiese situasies vir die psalm gerekonstrueer: Deissler (1979:382) en Kraus (1966:672), byvoorbeeld, verbind die psalm aan die loothuttefees en Weiser (1955:432) verbind die psalm met die sogenaamde verbondsvernuwingsfees. 
7 Vergelyk byvoorbeeld Gunkel \& Begrich (1933:94); Gunkel (1986:424). Gunkel (1986: 424) voeg egter daaraan toe dat die psalm ook himniese tone het. Mowinckel (1961:3) praat nie van 'n troonsbestygingslied nie, maar eerder van 'n troonsbestygingspsalm. Volgens Mowinckel (1962:109) is die troonsbestygingspsalms egter 'principally hymns of praise with the usual character of such hymns'.

8 Westermann (1977:111), byvoorbeeld, stel dit soos volg: 'Es gibt weder eine Gattung der Thronbesteigungspsalmen, noch sind die so bezeichneten Psalmen durch gleichmäßige Gattungsmerkmale verbunde. Es handelt sich vielmehr bei diesen Psalmen durchweg um Mischformen, die von ganz verschiedene Gattungen herkommen'.

${ }^{9}$ Kraus (1966:671), byvoorbeeld, praat van die psalm as 'n himne, nog meer besonder as 'n ‘Jahwe-Königshymne'. Kuntz (1967:209) wys ook op die himniese aard van die psalm.

10 Gunkel (1917:139) merk oor die psalm op: 'Ein geschichtlicher Anlaß des Psalms ist ebensowenig wie bei den andern eschatologischen Liedern anzunehmen'. Nötscher (1953:193) motiveer dit soos volg: 'Das Gericht wird von der Zukunft erwartet, ausgemalt wird es aber in Bildern, die der Vergangenheit entnommen sind'. Vergelyk verder ook Kittel (1922:317); Oesterley (1939:424); Kraus (1966:671); Dahood (1986:361); Fohrer (1993:81).

11 Kirkpatrick (1903:579) dink spesifiek aan die 'Restoration from Babylon as the occasion of the Psalm'. Briggs \& Briggs (1925:307) verbind sommige dele van die psalm aan die Makkabese tyd.

12 Howard (1986:103), kom op grond van die werkwoordsvorme in Psalm 97 tot 'n vooragste eeuse, maar met sekerheid tot 'n voor-eksiliese ontstaansdatum. Aanhangers van die troonsbestygingshipotese is verplig om die teks voor-eksilies te dateer: Vergelyk byvoorbeeld Mowinckel (1961:190-202); Day (1990:73); Schmid (1955:184-187). Die voorstanders van 'n voor-eksiliese datering vir die sogenaamde troonsbestygingspsalms voer aan dat Deuterojesaja byvoorbeeld van die psalms geleen het en nie andersom nie.

13 Westermann (1977:113) gebruik vormkritiese argumente, naamlik die - vir hom - uitsonderlike lofoproep aan die einde van die psalm, as motivering dat die psalm laat sou ontstaan het. Lescow (1992:94) is ook van mening dat die Psalm uit 'spät-nachexilischer Zeit' kom op grond van die feit dat die psalm so baie stof uit ander dele van die Ou Testament ontleen. Van der Ploeg (1974:155) kieș ook vir 'n na-eksiliese datering, maar wel voor $300 \mathrm{v}$ 
C. Hoewel Kissane (1954:127) die psalm ná-eksilies dateer, sê hy tog: 'The date cannot be determined more precisely'. Vergelyk byvoorbeeld ook Nötscher (1954:195); Kraus (1966: 671); Jeremias (1965:4), Loretz (1979:65) en Booij (1994:161) wat vir 'n na-eksiliese datering kies.

14 Gray (1979:69), byvoorbeeld, dateer vers 1-6 voor-eksilies en vers 7ev na-eksilies. Loretz (1988:345-346) is van mening dat, hoewel sekere dele van die teks (soos vers 1, 6 en die teofanie, vers $2-5$ ) uit die voor-eksiliese tyd kom, die teks in sy huidige gestalte tog uit ciie ná-eksiliese tyd dateer.

15 Hoewel Kuntz (1967:204) daarop wys dat Psalm 97 baie geykte vorme bevat wat aan ander dele van die Ou Testament ontleen is, sê hy tog: 'these traditional phrases have been creatively gathered into a dynamic whole'. Jeremias (1987:138) praat ook van die opbou as 'gekünstelt'. Leupold (1977) merk op: 'Despite the high ratio of quotations the work of weaving them together into a homogeneous whole is so skillfully done that the whole psalm makes the impression of being an original composition'. Beuken (1974:102) praat van 'n 'betekenisvolle struktuur'. Ook Kirkpatrick (1903:579) wys daarop dat die digter van Psalm 97 al sy stof aan die res van die Ou Testament ontleen. Tog noem hy die digter 'n 'masterly hymn-writer'.

16 Oesterley (1939:424) stel dit sooŝ volg: 'There is to some extent a lack of logical thoughtsequence and the impression is gained that familiar phrases have been gathered together rather than that the psalmist has composed an original hymn'. Duhm (1922:356) noem die digter 'n 'mittelmäßiger Poet'.

17 Westermann (1977:113) gebruik juis vormkritiese argumente om vers 2-5 - wat hy 'n 'Schilderung einer Epiphanie Gottes' noem — as sekondêr aan te dui. Weiser (1955:432, voetnoot 3) wys egter met reg daarop dat Westermann die stelling nóg verklaar nóg motiveer. Loretz (1988:344-346) beskou slegs vers 1 en 6 as oorspronklik waarby mettertyd kommentaar en herinterpretasie gevoeg is: $2-5$ verbreek die samehang tussen 1 en 6 (1988: 338; vgl ook Loretz 1979:65); $2 b$ is ook 'n 'Einschub' (1988:338); so is 5b ook 'n 'Zusatz' (1988:339); $7 \mathrm{a}$ en $7 \mathrm{~b}$ is ook sekondêr en $7 \mathrm{c}$ is 'n glosse en 'n uitbreiding op 7a-7b (1988:339). Mowinckel (1957:17) is van mening dat 7-10 oorspronklik deel kon gewees het van 'n ouer gedig wat deur die digter van Psalm 97 hier gebruik is. Lescow (1992:93) beskou vers 5 as 'n 'nachträgliche Erweiterung' vanweë die prosaïse aard daarvan en omdat vers 5 hier die opeenvolgende 'hiqtil-/qatal-x-Formen' van 4-6 sou onderbreek. Ook Briggs \& Briggs (1925:305-307 en 312) dui verskillende glosses en byvoeginge aan. 
18 Sommige verklaarders kies vir 'n tweeledige indeling: König (1927:114-115) praat van twee 'logischen Strophen', naamlik 1-6 en 7-12. Kyk ook Oesterley (1939:424-426); Anderson (1981:686-690). Kuntz (1967:206-208) het dieselfde tweeledige verdeling (1-6 en 712), maar hy gee ook onderverdelings aan, naamlik: 1-2, 3-6, 7-9 en 10-12. Fohrer (1993:80-83) kies ook vir ' $n$ tweeledige indeling, maar hy praat van 1-5 en 6-12.

Herkenne (1936:320-321) maak die volgende indeling: 1-6, 7-10 en 11-12. Howard (1986:105-106) sluit daarby aan, maar eintlik handhaaf hy ook 'n tweedeling, naamlik 1-9 wat oor die koningskap van Jahwe en die gevolge daarvan handel en 10-12 wat 'n 'admonition' tot die gelowiges is. Dahood (1986:361), Lamparter (1965:151-154) en Tate (1990: 518) sluit ook hierby aan.

Kittel (1922:318-320) se indeling is: 1, 2-6, 7-9 en 10-12; Kraus (1966:671) s'n (1-2, 3-6, 7-9 en 10-12) sluit hierby aan; en dié van Jeremias (1987:137) is: 1, 2-5, 6-9, en 10-12. Kidner (1975:350-351) se indeling stem feitlik hiermee ooreen, naamlik: 1-5, 6-9 en 10-12. Schmidt (1934:179) se indeling vertoon ook ooreenkomste hiermee, maar is net meer gedetailleerd: 1-5, 6-7, 8-9 en 10-12; so ook die indeling van Eaton (1967:235-237), naamlik 1-2, 3-5, 6-9, 10-12.

Westermann (1977:113) gebruik vormkritiese kriteria om die volgende indeling te maak: $1,2-5,6-8$, en 9-12.

Kissane (1954:127-129) sê dat daar vier strofes van drie verse elk is: 1-3, 4-6, 7-9 en 10-12; so ook Kirkpatrick (1903:579, hy noem dit 'stanzas of equal lenght') en Leupold (1977:687). Nowack (1888:402-403) en Duhm (1922:356-357) het lank tevore reeds dieselfde indeling gemaak.

19 Hossfeld \& Zenger (1993:7) merk in hierdie verband met reg op: 'Daß das Psalmenbuch dennoch nicht ein amorpher Haufe von zusammengesetzen Einzelelementen ... oder eine mehr oder weniger zufälige Aneinanderreihung von beziehungslos nebeneinander gestellten Einzellieder und -gebeten ... ist, wird in der jüngsten Psalmforschung mehr und mehr gesehen und herausgearbeitet'. Kyk ook Millard (1994); McCann (1993); Schreiner (1988) en Deissler (1988) in die verband.

20 Hier word vanselfsprekend nie op dié saak ingegaan nie. Vergelyk egter Howard (1986) vir 'n volledige bespreking.

21 Vergelyk byvoorbeeld Kraus (1966:672-675); Van der Ploeg (1974:155-157); Deissler (1979:382-383) wat aandui met watter ander dele van die Ou Testament Psalm 93 ooreenstem. 
22 Hoewel ek uiteraard bewus is van die problematiek rondom die term 'finale teks' en die gelykstelling daarvan aan BHS; die bestaan van ander tekste naas die Hebreeuse teks en dat die MT nie simplisties aan die Ou Testament gelykgestel kan word nie (vgl bv Deist 1989:920; Deist 1994:172), is ek tog oortuig daarvan dat 'n mens van die Ou Testament, en in hierdie geval van Psalm 97, kan praat.

23 Vergelyk Prinsloo (1993a:250-251, voetnoot 13) en Prinsloo (1993b:630) vir die verskillende moontlikhede waarmee die uitdrukking vertaal kan word.

$24 \mathrm{Vir}$ 'n volledige bespreking van die teofaniebeskrywing, vergelyk Jeremias (1965:100111). Jeremias (1965:151) sê dat die teofaniebeskrywing twee basiese elemente bevat, naamlik die koms van Jahwe en die uitwerking daarvan op die natuur (kyk ook Mowinckel 1961:56). Ek gaan nie hier in op die debat oor die terminologie nie: Westermann (1977:6975) onderskei byvoorbeeld tussen teofanie en epifanie; epifanie is 'n verskyning tot hulp vir die volk ('Gott kommt herbei um seinem Volk zu helfen'), maar teofanie beskryf hy as: 'Gott erscheint, um sich zu offenbaren (und durch einen Mittler seinem Volk etwas zu sagen)'. Vergelyk ook Mettinger (1982:118) in die verband.

25 Jeremias (1987:138; vgl ook Jeremias 1965:29-30) wys juis daarop dat met 2b (צִ מכוק

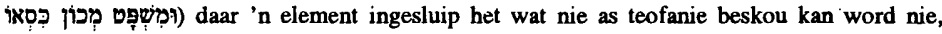
maar dat die versbeen desnieteenstaande goed by die res van die psalm inpas. Lescow (1992: $94)$ is egter van mening dat $2 \mathrm{~b}$ ook deel van die teofaniebeskrywing is. Kittel (1922:318) sê tereg van hierdie beskrywings dat hulle hulle ou, mitologiese inhoud verloor het en dat dit slegs beeldryke taal is om die mag, die grootheid en die heerlikheid van Jahwe te beskryf. Kuntz (1967:212) wys daarop dat die Sinaibeskrywing hier verskerp en uitgebou word: '.. the intensification is suitable to the specific purpose of the cultic theophany, for in the present passage it is not Israel but all peoples who are imagined as witnesses to Yahweh's theophanic presence'.

26 Kidner (1975:350) verwoord dit as die 'unapproacable holiness and hiddenness' van Jahwe. Kuntz (1967:210) wys daarop dat 'Yahweh is represented in traditional Israelite terms as one who is at once revealed yet mysteriously hidden'.

27 Brunner (1958:426-428) bespreek ook die ander gedeeltes in die Ou Testament waar van dié woordpaar as fondament vir Jahwe se troon gepraat word. Sy gevolgtrekking is dat die voorstelling na Egiptiese bronne terug te voer is. 
28 Vir 'n omskrywing van dié stylfiguur, vergelyk Watson (1986:343-346) en Bühlmann \& Scherer (1973:36).

29 Om die perfektumvorme in 4-6 te beskou as 'n verwysing na ' $n$ spesifieke historiese gebeurtenis in die verlede, of om dit te beskou as 'n kultiese geleentheid wat pas afgehandel is, of om dit eskatologies te interpreteer as profetiese perfekta, sou wees om te veel in die tydsvorme in te lees. Michel (1960:16) sề dus met reg: 'Hier läßt sich über die Zeitstufe nichts Sicheres sagen, da die Exegese der Thronbesteigungspsalmen umstritten ist'. Binne die konteks en in lyn met die funksie van die psalm, sou die doel van die perfekta eerder wees om die sekerheid dat Jahwe koning is, nog meer te beklemtoon.

30 Vergelyk byvoorbeeld Duhm (1922:357); Oesterley (1939:425); Kraus (1966:670); Kuntz (1967:206, voetnoot 64); Deissler (1979:382) wat die uitdrukking uitlaat.

31 Vogt $(1965: 208)$ noem 'n voorbeeld in Psalm 68:9 waar dieselfde stylfiguur voorkom. Jeremias (1987:137) meen ook ten op sigte van die uitdrukking: 'Die Wiederholung ist beabsichtigt'.

32 Westermann (1970:230ev) wys daarop dat כָבְּ dikwels in noue verband met die Sinaitradisie voorkom. Ook hier in Psalm 97 word, soos reeds aangetoon, geykte terminologie uit dié tradisie gebruik.

33 Kuntz (1967:208) formuleer dit soos volg: 'The climatic note of the theophany is achieved in the balanced bicolon of v. 6 in which each colon contains the verb, then, the witnessing subject, and finally, the divine aspect'.

34 Van der Lugt (1980:365-366) se strofale verdeling is 1-3, 4-6, 7-9 en 10-12. Volgens hom vorm 1-3 en 4-6 sowel materieel as formeel 'n sinonieme strofale paar, terwyl die laaste twee strofes (7-9 en 10-12) in 'n antitetiese parallelle verhouding staan. Gunkel (1986:425) se opmerking ten op sigte van die hele psalm is dus ook hier van toepassing: 'Regelmaßige Strophenbildung tritt nicht hervor'.

35 Die werkwoord השֶׁת sou ook as 'n imperatief vertaal kon word (vgl die $L X X$, Siriese vertaling - Herkenne 1936:321; Dahood 1986:360) en as 'n soort van sarkastiese oproep beskou word. Dit sou egter ongewoon wees om hier so 'n geïsoleerde imperatief aan te tref. Die waarskynlikste is dus om afgodsbeelde aanbid, tot skande sal kom omdat al die gode, selfs dié wat deur afgodsbeelde 
verteenwoordig word, onderdanig is aan Jahwe. Die meeste eksegete aanvaar dan ook laasgenoemde standpunt, vergelyk byvoorbeeld Nowack (1888:406); Kraus (1966:670); Johnson (1967:97); Tate (1990:517 voetnoot $7 b)$.

36 Die voorstanders hiervan (vgl bv Gunkel 1917:134; Duhm 1922:357; Schmidt 1934:179; Gunkel 1986:426; Kittel 1922:317; Oesterley 1939:425; Kissane 1954:128; Kraus 1966:670; Anderson 1981:691; Dahood 1986:360; Jeremias 1987:137) redeneer onder andere dat die MT-lesing nie by die konteks inpas nie en dat Jahwe die subjek van die werkwoord behoort te wees. Hulle meen dat daar dittografie plaasgevind het en verander ירָּ gevolglik אa אה (enkelvoud partisipium, 'Hy wat liefhet') met Jahwe as subjek. Die tekskritiese

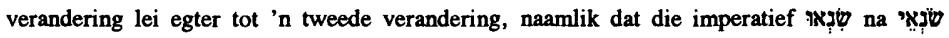
('haters') verander word.

37 Die $L X X$ ondersteun ook die MT in die verband. Howard (1986:101) voer die parallelle en ooreenkomste tussen $10 \mathrm{a}$ en $12 \mathrm{a}$ as rede aan waarom die voorgestelde tekskritiese verandering nie aangebring behoort te word nie: Albei versbene bevat sowel imperatiewe as die naam Jahwe. Nog 'n rede wat teen die teksverandering ingebring kan word, is dat die

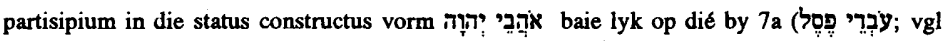

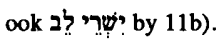

38 Dit is die een saak waaroor die meeste navorsers saamstem, vergelyk die kommentare ad loc.

39 Op grond van sommige manuskripte en vertalings word die lesing צר ('is gesaai') soms verander na זٓ ('uitstraal'). Die argument wat gebruik word, is dat die beeld van 'saai' nie by 'lig' pas nie, dat אור nêtrens in die Ou Testament in dié kombinasie voorkom nie en

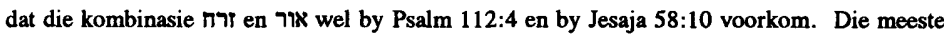
navorsers steun die verandering ( $\mathrm{vgl}$ die kommentare ad loc). Tog is daar ook navorsers wat die MT wil behou. Beuken (1974:109, endnoot 8), byvoorbeeld, betoog vir die behoud van die MT: “"Zaaien" past funktioneel beter in de lijn door het motiefwoord smh aangebracht'.

40 Watson (1986:208) verkies die term 'terrace pattern'.

\section{Literatuurverwysings}

Anderson, A A 1981. Psalms (73-150). 2nd ed. Grand Rapids: Eerdmans (NeCBC.)

Berlin, A 1993. The role of the text in the reading process. Semeia 62, 143-147. 
Bernhardt, K-H 1961. Das Problem der altorientalische Königsideologie im Alten Testament: Unter besonderer Berücksichtigung der Geschichte der Psalmexegese dargestellt und kritisch gewürdigt. Leiden: Brill. (VTS 8.)

Beuken, W A M 1974. De vreugde om JHWH's heerschappij: Een struktuuranalyse van Ps. 97, in Boertien, M, Van Daalen, A G, Hoogewoud, F J \& Plantenga, E H (reds), Verkenningen in een stroomgebied: Proeven van oudtestamentisch onderzoek ter gelegenheid van het afscheid van Prof $\operatorname{Dr} M A$ Beek van de Universiteit van Amsterdam. Amsterdam: Huisdrukkerij Universiteit van Amsterdam.

Booij, Th 1994. Psalmen III (81-110). Nijkerk: Callenbach (POT.)

Botha, P J 1986. Die teologiese funksie van die torah-woordveld in die driehoeksverhouding Jahwe-vrome-vyand in Psalm 119. DD-proefskrif, Universiteit van Pretoria.

1989. Resepsieteorie: Konkurrent of komplement van die teksimmanente eksegese? Skrif en Kerk 10/2, 113-127.

Briggs, C A \& Briggs, E G 1925. A critical and exegetical commentary on the Book of Psalms, II. Edinburgh: Clark (ICC.)

Brunner, K 1958. Gerechtigkeit als Fundament des Thrones. VT 8, 426-428.

Bühlmann, W \& Scherer, K 1973. Stilfiguren der Bibel: Ein kleines Nachschlagewerk. Fribourg: Schweizerisches Katholisches Bibelwerk (Biblische Beiträge 10.)

Carelsen, H L 1991. Levitikus 13 en 14: 'n Model vir die interpretasie van Ou-Testamentiese wetstekste. DD-proefskrif, Universiteit van Pretoria.

Coetzee, J H 1986. Die spanning tussen God se 'verborge wees' en sy 'ingrype om te red'. 'n Eksegetiese ondersoek na 'n aantal klaagpsalms. DD-proefskrif, Universiteit van Pretoria.

Dahood, M 1986. Psalms, II. 12th pr. New York: Doubleday (AncB.)

Day, J 1990. Psalms. Sheffield: JSOT Press (Old Testament Guides.)

Deissler, A 1979. Die Psalmen. 2.Aufl. Düsseldorf: Patmos.

Deissler, A 1988. Die Stellung von Psalm 2 im Psalter: Folgen für die Auslegung, in Schreiner, J (Hrsg), Beiträge zur Psalmenforschung, 73-84. Würzburg: Echter Verlag (Forschung zur Bibel 60.)

Deist, F E 1973. Ou-Testamentiese eksegese en algemene literatuurwetenskap. NGTT 14, 75-81.

1983. Bibelinterpretation und/als Ideologiekritik. OTE 1, 26-48.

1988. 'Gekontroleerde' eksegese en/of 'kreatiewe' uitleg. HTS 44/4, 39-54.

1989. Is die Massoretiese teks die Ou Testament? Skrif en Kerk 10/1, 9-20.

1994. Onlangse konsepte in teksuitleg en hulle konsekwensies vir die (gereformeerde) teologie. In die Skriflig 28/2, 165-178. 
Duhm, B 1922. Die Psalmen. 2. Aufl. Tübingen: Mohr. (KHC 14.)

Eaton, J H 1967. Psalms. London: SCM.

Fohrer, G 1993. Psalmen. Berlin: De Gruyter.

Gunkel, H 1917. Ausgewählte Psalmen. 4. Aufl. Göttingen: Vandenhoeck.

1986. Die Psalmen. 6. Aufl. Göttingen: Vandenhoeck. (HKAT II/2.)

Gunkel, H \& Begrich, J 1933. Einleitung in die Psalmen: Die Gattungen der religiösen Lyrik Israels. Göttingen: Vandenhoeck. (HKAT 2.)

Gray, J 1979. The biblical doctrine of the reign of God. Edinburgh: Clark.

Herkenne, H 1936. Das Buch der Psalmen. Bonn: Peter Hanstein (HSAT 5/2.)

Howard, D M 1986. The structure of Psalms 93-100. Ann Arbor: University Microfilms International.

Hossfeld, F-L \& Zenger, E 1993. Die Psalmen: Psalm 1-50. Würzburg: Echter Verlag (NEB 29.)

Human, D J 1993. Die begrip 'be rit' in 'n aantal klaagpsalms: 'n Perspektief. DDproefskrif, Universiteit van Pretoria.

Jeremias, J 1965. Theophanie: Die Geschichte einer alttestamentliche Gattung. Neukirchen-Vluyn: Neukirchener Verlag (WMANT 10.)

- 1987. Das Königtum Gottes in den Psalmen. Israels Begegnung mit den kanaanäischen Mythos in den Jahwe-König-Psalmen. Göttingen: Vanderhoeck. (FRLANT 141.)

Johnson, A R 1967. Sacral kingship in Ancient Israel. Cardiff: University of Wales Press.

Kidner, D 1975. Psalms 73-150. London: Intervarsity Press.

Kirkpatrick, A F 1903. The book of Psalms. Cambridge: Cambridge University Press.

Kirkpatrick, J D 1993. Eskatologie in die boek Sefanja. DD-proefskrif, Universiteit van Pretoria.

Kissane, E J 1954. The book of Psalms, II. Dublin: Browne \& Nolan.

Kittel, R 1922. Die Psalmen. 3 und 4 Aufl. Leipzig: Deichertsche Verlagsbuchhandlung. (KAT 13.)

König, E 1927. Die Psalmen. Gütersloh: Bertelsmann.

Kraus, H-J 1966. Psalmen, 2.Teilband. 3. Aufl. Neukirchen: Neukirchener Verlag. (BKAT XV/2.)

Kriek, H S 1993. Psalm 37: Reading parallelism. DD-proefskrif, Universiteit van Pretoria.

Kuntz, J K 1967. The self-revelation of God. Philadelphia: The Westminster Press.

Lamparter, H 1965. Das Buch der Psalmen. 2.Aufl. Stuttgart: Calwer Verlag (BAT 15.) 
Le Roux, J H 1993. A story of two ways: Thirty years of Old Testament scholarship in South Africa. Pretoria: Verba Vitae. (OTE Suppl 2.)

Lescow, T 1992. Das Stufenschema: Untersuchungen zur Struktur alttestamentlicher Texte. Berlin: De Gruyter. (BZAW 211.)

Leupold, H C 1977. The Psalms. Herts: Evangelical Press.

Lipinski, E 1963. Yahweh mâlak. Biblica 44, 405-460.

Loader, J A 1978. Gedagtes oor gekontroleerde eksegese. HTS 34, 1-40.

Loretz, O 1979. Die Psalmen, II: Beitrag der Ugarit-Texte zum Verständnis von Kolometrie und Textologie der Psalmen. Psalm 90-150. Neukirchen-Vluyn: Neukirchener Verlag.

- 1988. Ugarit-Texte und Thronbesteigungspsalmen: Die Metamorphose des Regenspenders Baal-Jahwe. Münster: Ugarit-Verlag. (Ugaritisch-Biblische Literatur 7.)

McCann, J C (ed) 1993. The shape and shaping of the psalter. Sheffield: Sheffield Academic Press. (JSOT SS 159.)

Mettinger, T N D 1982. The dethronement of Sabaoth: Studies in the Shem and Kabod theologies. Gleerup: CWK.

Michel, D 1960. Tempora und Satzstellung in den Psalmen. Bonn: Bouvier (AET 1.)

Millard, M 1994. Die Komposition des Psalters: Ein formgeschichtlicher Ansatz. Tübingen: Mohr. (Forschungen zum Alten Testament 9.)

Mowinckel, S 1957. Real and apparent tricola in Hebrew psalm poetry. Oslo: Kommisjon Hos Aschehoug.

- 1961. Psalmenstudien, II. Amsterdam: Schippers.

— 1962. The Psalms in Israel's worship, I. Translated by D R Ap-Thomas. Oxford: Blackwell.

Nowack, W 1888. Die Psalmen, Zweiter Band. 3. Aufl. Gotha: Friedrich Andreas Perthes.

Nötscher, F 1953. Die Psalmen. 4. Aufl. Würzburg: Echter Verlag. (Echter Bibel 1.)

Oesterley, W O E 1939. The Psalms, II. London: SPCK.

Prinsloo, G T M 1989. 'n Literêr-eksegetiese analise van die boek Habakuk. DDproefskrif, Universiteit van Pretoria.

Prinsloo, W S 1979. Die metodiek van eksegese: 'n Diskussie. NGTT 20/3, 189-200. 1988. Die histories-kritiese metode(s) in perspektief. Skrif en Kerk 9/2, 196209.

1990. Oor eksegetiese metodes en nog wat: 'n Gesprek. HTS 46, 144-152. 1992. Weer eens: Eksegetiese metodes. Skrif en Kerk 13/2, 182-188. 
Prinsloo, W S 1993a. Psalm 93: Jahwe is van altyd af Koning oor alles en almal. NGTT 34/3, 248-261.

1993b. Psalm 99: Die Here, ons God, is heilig. HTS 49/3, 621-636.

- 1994. Psalm 98: Sing 'n nuwe lied tot lof van die Koning, Jahwe. HTS 50/1 \& 2, 155-168.

Rendtorff, R 1993. The paradigm is changing: Hopes - and fears. Biblical Interpretation $1 / 1,34-53$.

Rogerson, J W 1991. Exegese als Literaturwissenschaft: Revisited, in Gross, W, Irsigler, H \& Seidl, T (Hrsg), Text, Methode und Grammatik: Wolfgang Richter zum 65. Geburtstag. St Ottilien: Eos Verlag.

Schmid, H 1955. Jahwe und die Kulttraditionen von Jerusalem. ZAW 67, 168-187.

Schmidt, H 1934. Die Psalmen. Tübingen: Mohr. (HAT 15.)

Schreiner, J 1988. Zur Stellung des Psalms 22 im Psalter: Folgen für die Auslegung, in Schreiner, J (Hrsg), Beiträge zur Psalmenforschung, 241-278. Würzburg: Echter Verlag. (Forschung zur Bibel 60.)

Snyman, S D 1985. Antiteses in die boek Maleagi. DD-proefskrif, Universiteit van Pretoria.

Swanepoel, M G 1987. Die teologie van Esegiël 33 tot 39. DD-proefskrif, Universiteit van Pretoria.

Tate, M E 1990. Psalms 51-100. Dallas: Word Books. (Word Biblical Commentary 20.)

Valeton, J J P 1913. Die Psalmen. Nijmegen: Ten Hoet.

Van der Lugt, P 1980. Strofische structuren in de Bijbels-Hebreeuwse poëzie. Kok: Kampen.

Van der Ploeg, J P M 1974. Psalmen, II. Roermond: Romen. (BOT VII/b.)

Van Zyl, A H 1981. Eksegese! In die maalstroom? Skrif en Kerk 2/1, 43-50.

Viviers, H 1990. 'n Teksimmanente ondersoek na die samehang van die Mcalôt-psalms (Pss. 120-134). DD-proefskrif, Universiteit van Pretoria.

Vogt, E 1965. 'Die Himmel troffen' (Ps 68,9)? Biblica 46, 207-209.

Watson, W G E 1986. Classical Hebrew poetry: A guide to its techniques. 2nd ed. Sheffield: The University of Sheffield Press. (JSOT SS 26.)

Weiser, A 1955. Die Psalmen: II/Psalm 61-150. 4. Aufl. Göttingen: Vandenhoeck. (ATD 15.)

Westermann, C 1970. Die Herrlichkeit Gottes in der Priesterschrift, in Stoebe, H J, Stamm, J J, \& Jenni, E (Hrsg), Wort - Gebot - Glaube: Beiträge zur Theologie des Alten Testaments. Zürich: Zwingli Verlag. (ATANT 59.) 1977. Lob und Klage in den Psalmen. 5. Aufl. Göttingen: Vandenhoeck. 